\title{
Lepidine Orange derivative as a new dye for sensitive fluorescent detection of DNA
}

\author{
Yu. V. Didan ${ }^{1}$, D. V. Kryvorotenko², V. V. Negrutska ${ }^{2}$ I. Ya. Dubey ${ }^{2}$ \\ ${ }^{1}$ Taras Shevchenko National University of Kyiv \\ 64/13, Volodymyrska Str., Kyiv, Ukraine, 0160 \\ ${ }^{2}$ Institute of Molecular Biology and Genetics, NAS of Ukraine \\ 150, Akademika Zabolotnoho Str., Kyiv, Ukraine, 03680 \\ dubey@imbg.org.ua
}

\begin{abstract}
The aim. To study new cyanine dye LO-7 as a reagent for dsDNA visualization in electrophoretic gels. Methods. Gel electrophoresis, restriction, fluorescence detection, mobility shift assay. Results. LO-7 binds to DNA to form stable highly fluorescent complexes. As little as $80 \mathrm{pg}$ DNA can be detected in LO-7-stained agarose gel using a laser scanner, and $0.3 \mathrm{ng}$ with UV-transilluminator. This sensitivity is several times higher than can be achieved with ethidium bromide, and close to that of SYBR Green I. Conclusions. LO-7 belongs to the most efficient stains for dsDNA visualization and thus can be used in bioanalytical applications where high sensitivity is required.

Keywords: fluorescent dyes, cyanines, gel electrophoresis, nucleic acids, detection.
\end{abstract}

\begin{abstract}
Introduction. Non-radioactive labeling of biomolecules has been studied extensively for several decades. Fluorescent detection, either in solution or in electrophoretic gels, is the most common type of non-radioactive detection, and a wide variety of fluorescent dyes have been developed for this purpose [1-3]. The detection of DNA and RNA with fluorescent dyes has a variety of analytical and diagnostic applications in molecular and cell biology, biotechnology and medicine $[1,4]$. Currently the majority of fluorescent dyes commonly used for nucleic acids visualization assays belong to the cyanine family [2, 5], since these molecules display high affinity for nucleic acids, strong absorption in the visible spectral range and often sharp increase of fluorescence when interacting with nucleic acids [6-8]. The number of established fluorophores of this group is quite large, but the search for new highly efficient dyes is still relevant [5]. In this paper, we present a new cyanine dye LO-7 (Lepidine Orange derivative), a structural analog of well known dyes Thiazole Orange [9] and SYBR Green I from «Mo-
\end{abstract}

(C) Institute of Molecular Biology and Genetics, NAS of Ukraine, 2013 lecular Probes» (USA) (now «Invitrogen») [10, 11], as a new highly sensitive fluorescent stain for DNA detection in agarose gels.

Materials and methods. A series of LO dyes were synthesized as previously described [12]. $p B R 322$ plasmid DNA («Fermentas», Lithuania) in TE buffer (100 $\mathrm{ng} / \mu \mathrm{l})$ was serially diluted with TE to obtain samples with concentrations of 100, 50, 25, 12.5, 6.25, 3, 1.5 and $0.75 \mathrm{ng} / \mu \mathrm{l}$. For sensitivity assay, plasmid DNA was restricted with BstNI enzyme («Fermentas») and then serially diluted (1:4) to get 4 samples with DNA concentrations of $23,5.75,1.44$ and $0.36 \mathrm{ng} / \mu \mathrm{l}$. DNA samples for mobility shift assays were incubated for $30 \mathrm{~min}$ with LO dye before loading the gels. Agarose gel electrophoresis was performed in $0.5 \times$ TBE buffer. DNA samples in TE buffer were loaded on the gel after adding the tracking dyes xylene cyanol and bromophenol blue in $30 \%$ glycerol to concentration $0.025 \%$. Electrophoresis was run for $1.5 \mathrm{~h}$ at a constant voltage $100 \mathrm{~V}(\sim 50 \mathrm{~mA})$. The gel was stained for $30 \mathrm{~min}$ at room temperature in LO-7 solution prepared by diluting the stock $(20 \mathrm{mM}$ in dimethylsulfoxide) with water (1: 10000). DNA bands 


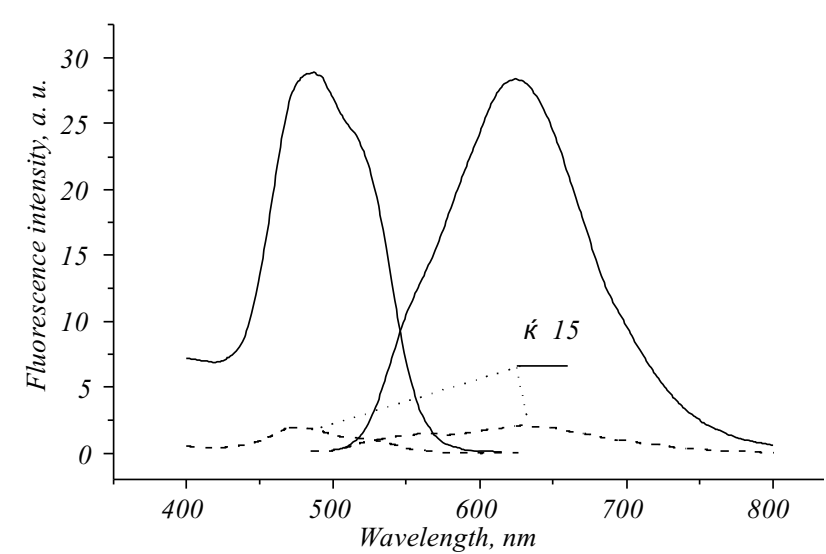

Fig. 1. Excitation (1) and emission (2) spectra of free LO-7 (dashed lines) and its complex with salmon sperm DNA (solid lines) in water. LO-7 concentration $10^{-5} \mathrm{M}$, dye/bp ratio $1: 1$. Fluorescence was excited at $490 \mathrm{~nm}$

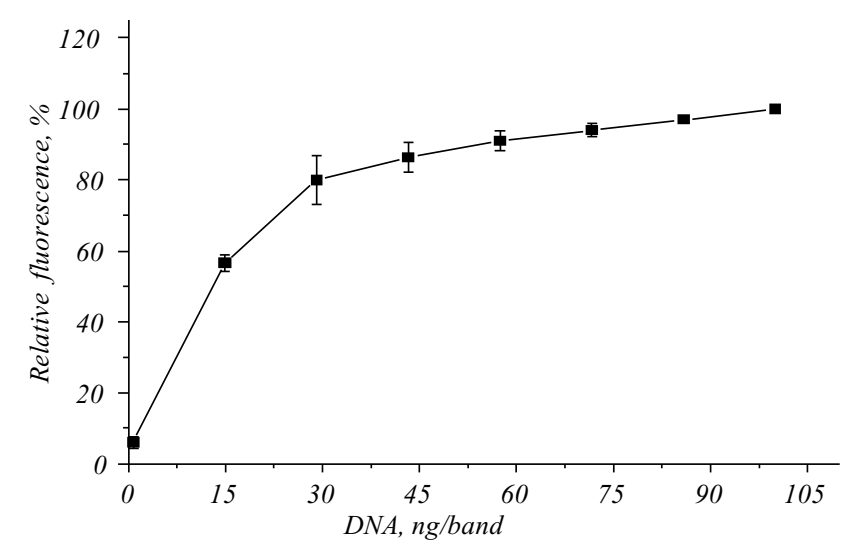

Fig. 2. Relative fluorescence of LO-7-stained plasmid DNA in agarose gel (data from 3 independent experiments)

were detected with a UV-transilluminator Macrovue 2011 («LKB», Sweden) or laser gel scanner PharosFX Molecular Imager («Bio-Rad», USA). The rates of dissociation of dye-DNA complexes under the conditions of gel electrophoresis were determined according to [13]. Fluorescence spectra were obtained with Cary Eclipse spectrofluorimeter («Varian», Australia).

Results and discussion. A series of new asymmetric monomethine cyanines LO (Lepidine Orange derivatives) with dialkyl- or arylalkylamino group at C-2 position of quinoline ring have been recently synthesized as potential DNA topoisomerase I inhibitors [12]. Five compounds of this series were found to completely inhibit this enzyme in DNA relaxation test system in vitro at concentration $2-10 \mu \mathrm{M}$, with $\mathrm{IC}_{90}$ value $\sim 1 \mu \mathrm{M}$ for the most active inhibitor. We have found that these virtually non-fluorescent compounds strongly interact with nucleic acids to form highly fluorescent complexes, thus allowing sensitive visualization of double-stranded DNA in agarose gels. The most efficient DNA stain LO-7 has been studied in detail in this work.

The binding of LO-7 to dsDNA results in great fluorescence increase (Fig. 1). Excitation and emission maxima $\lambda_{\max }$ ex/em are 476/625 and 485/625 nm for free and DNA-bound dye, respectively. A large Stokes shift $(140 \mathrm{~nm})$ is observed.

The dependence of relative fluorescence of LO-7DNA complexes in the gel on DNA quantity is shown in Fig. 2. Fluorescence intensity sharply increases between 0.5 and $15 \mathrm{ng}$ DNA, and the curve approaches saturation above $30 \mathrm{ng}$. The linear dependence allowing DNA quantification is observed in the range $0.5-5 \mathrm{ng}$.

LO-7 is a highly sensitive DNA stain. Fig. 3, $A$, shows a gel with various amounts of DNA (from 23 to $0.36 \mathrm{ng}$ per band). BstNI restrictase cuts $p B R 322$ at 6 discrete sites resulting in fragments of $1857,1060,929$, 383,121 and 13 base pairs (bp). The amount of each fragment in the lane was calculated from the total DNA concentration in the given sample multiplied by the fractional length of the DNA fragment relative to the total length of pBR322 (4361 bp). Thus the minimum quantity of dsDNA detected with a gel scanner at $488 \mathrm{~nm}$ is the 929 bp fragment, which corresponds to $77 \mathrm{pg}$. According to published data, the limit of detection of dsDNA in agarose gel is $0.5-5 \mathrm{ng}$ for ethidium bromide, $0.5 \mathrm{ng}$ for TOTO, $60 \mathrm{pg}$ for SYBR Green I and $25 \mathrm{pg}$ for SYBR Gold, the most sensitive fluorescent DNA stain currently available [2]. The minimum amount of dsDNA to be detected with SYBR Green I with common $365 \mathrm{~nm}$ UVtransilluminator was found to be $0.15 \mathrm{ng}$, whereas the detection limit for LO-7 is about $0.3 \mathrm{ng}$ DNA for the same sample (Fig. 3, B). Thus LO-7 sensitivity is much higher than that achieved with ethidium bromide or TOTO being comparable to that of SYBR Green I.

Electrophoretic mobility shift assay was used to characterize LO-7 binding to dsDNA. This assay simultaneously provides information on the stability, mobility and fluorescence of complexes [10]. A retardation of DNA band indicating the dye binding was observed upon increasing the dye/base pair ratio (dbpr) of prestained DNA samples above 0.05 . Sharp bands become diffuse and less intense at dbpr over 0.1 that may be due to the partial degradation or denaturation of DNA (Fig. 4). 

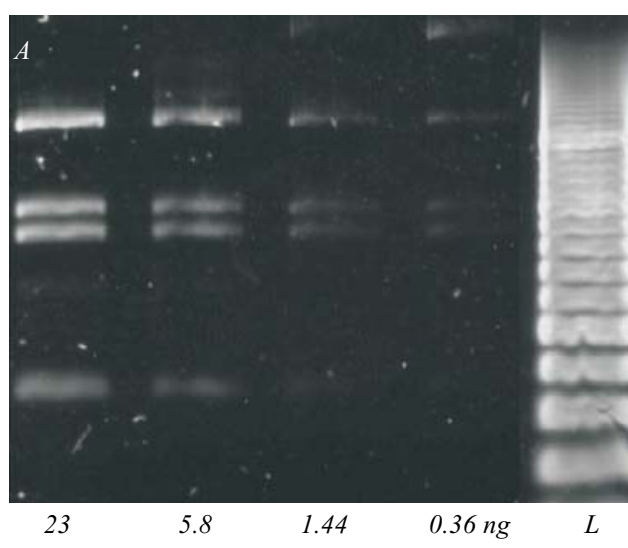

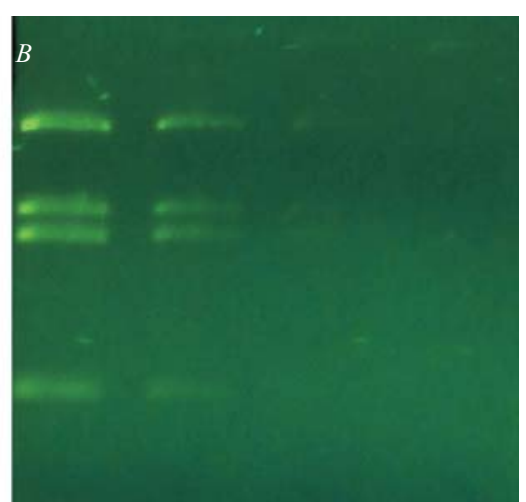

23

$0.36 n g$
5.8

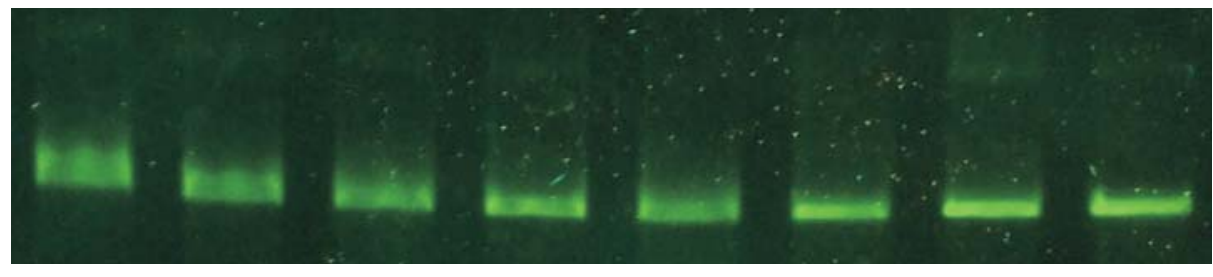

0.5
0.1
0.025

0.01

C

Fig. 3. DNA detection in LO-7stained $2 \%$ agarose gel with laser gel scanner $(A)$ and UV-transilluminator $(B)$. DNA dilution series $(23,5.8,1.44$ and $0.36 \mathrm{ng}$ of BstNI digested $p B R 322)$ were analyzed in $2 \%$ agarose gel poststained with LO-7; $L-100$ bp ladder (250 ng DNA)

Fig. 4. Electrophoresis of $\mathrm{LO} /$ DNA complexes at dye/base pair ratio from 0.01 to $1 ; C$ - control (plasmid DNA without preincubation with dye). DNA concentration $20 \mu \mathrm{M}$. Gel was stained with LO-7
Dissociation half-time for LO-7 complex with $p B R 322$ DNA in agarose gel was found to be ca. $15 \mathrm{~min}$ (for comparison, the reported $t_{1 / 2}$ values for TO and ethidium bromide complexes are about 4 min under the same conditions [13]). As complex is sufficiently stable under electrophoretic conditions, LO-7 can be used to stain DNA either after or before the electrophoresis (pre-staining).

Fluorescent detection of nucleic acids in the gel depends on the availability of dyes binding to them with high affinity and large fluorescence enhancement $[1$, $5-8,13]$. Strong binding of LO-7 to dsDNA is confirmed by both large emission increase upon interaction with DNA and mobility shift data, and is in full agreement with efficient DNA topoisomerase inhibition by this compound.

In conclusion, we propose a new cyanine dye LO-7 as a highly efficient reagent for DNA visualization in electrophoretic gels. Its remarkable sensitivity far exceeds that of classic ethidium bromide and is close to that of the current standard, SYBR Green I. This makes LO-7 useful for various biomedical applications, including the PCR, DNA quantification in restriction fragment mapping, band shift experiments, etc.

Acknowledgement. This work was supported by the NAS of Ukraine program «Fundamental problems of the development of new substances and materials for chemical industry» (grant N 30-13).
Authors thank Dr. M. Losytskyy for recording the fluorescence spectra.

\section{Ю. В. Дідан, Д. В. Криворотенко, В. В. Негруиька, І. Я. Дубей}

Похідна Лепідинового Оранжевого як новий барвник для чутливої флуоресцентної детекції ДНК

\section{Резюме}

Mета. Дослідження нового иіанінового барвника LO-7 як реагента при візуалізаиії дволаниюгової ДНК в електрофоретичних гелях. Методи. Гель-електрофорез, рестрикиія, флуоресиентна детекція, mobility shift (зміна електрофоретичної рухливості). Результати. LO-7 зв'язується з ДНК, утворюючи стійкі високофлуоресиентні комплекси. У пофарбованих ним агарозних гелях можна визначати 80 пг ДНК за допомогою лазерного сканера $i$ 0,3 нг - за використання УФ-трансілюмінатора. Подібна чутливість у кілька разів вищза, ніж у бромистого етидію, $і$ близька до такої для SYBR Green I. Висновки. LO-7 належить до найефективіших барвників для візуалізації дволаниюгової ДНК і може застосовуватись при виріменні біоаналітичних завдань, де необхідна висока чутливість.

Ключові слова: флуоресиентні барвники, иіаніни, гель-електрофорез, нуклеїнові кислоти, детекиія.

\section{Ю. В. Дидан, Д. В. Криворотенко, В. В. Негруикая, И. Я. Дубей}

Производное Лепидинового Оранжевого как новый краситель для чувствительной флуоресцентной детекции ДНК

Резюме

Цель работы состояла в изучении нового иианинового красителя LO-7 как реагента при визуализачии двухиепочечной ДНК в электрофоретических гелях. Методы. Гель-электрофорез, рестрикиия, флуоресиентная детекиия, mobility shift (изменение электрофоретической подвижности). Результаты. LO-7 связывается с 
ДНК, образуя устойчивые высокофлуоресцентные комплексы. В окрашенных им агарозных гелях можно определить $>80$ пг ДНК при помощчи лазерного сканера и 0,3 нг - при использовании УФтрансиллюминатора. Подобная чувствительность в несколько раз выше, чем у бромистого этидия, и близка к таковой для SYBR Green I. Выводы. LO-7 принадлежит к наиболее эффективным красителям для визуализации двухиепочечной ДНК и может применяться для решения биоаналитических задач, где необходима выссокая чувствительность.

Ключевые слова: флуоресчентне красители, цчианины, гельэлектрофорез, нуклеиновые кислоты, детекция.

\section{REFERENCES}

1. Kricka L. J. Stains, labels and detection strategies for nucleic acids assays // Ann. Clin. Biochem.-2002.-39, Pt 2.-P. 114-129.

2. Haughland R. P. The Handbook - a guide to fluorescent probes and labeling technologies / $10^{\text {th }}$ ed.-Eugene: Molecular Probes, 2005.-1126 p.

3. Goncalves M. S. Fluorescent labeling of biomolecules with organic probes // Chem. Rev.-2009.-109, N 1.-P. 190-212.

4. Su X., Xiao X., Zhang C., Zhao M. Nucleic acid fluorescent probes for biological sensing // Appl. Spectroscop.-2012.-66, N 11.-P. 1249-1262.

5. Deligeorgiev T. G., Kaloyanova S., Vaquero J. J. Intercalating cyanine dyes for nucleic acid detection // Rec. Pat. Mater. Sci.2009.-2, N 1.-P. 1-26.

6. Yarmoluk S., Kovalska V., Losytskyy M. Symmetric cyanine dyes for detecting nucleic acids // Biotech. Histochem.-2008.-83, N 3.-P. 131-145.
7. Levitus M., Ranjit S. Cyanine dyes in biophysical research: the photophysics of polymethine fluorescent dyes in biomolecular environments // Q. Rev. Biophys.-2011.-44, N 1.-P. 123-151.

8. Tatikolov A. S. Polymethine dyes as spectral-fluorescent probes for biomacromolecules // J. Photochem. Photobiol. C.-2012.13, N 1.-P. 55-90.

9. Nygren J., Svanvik N., Kubista M. The interaction between the fluorescent dye thiazole orange and DNA // Biopolymers.1998.-46, N 1.-P. 39-51.

10. Zipper H., Brunner H., Bernhagen J., Vitzthum F. Investigations on DNA intercalation and surface binding by SYBR Green I, its structure determination and methodological implications // Nucleic Acids Res.-2004.-32, N 12.-e103.

11. Trantakis I. A., Fakis M., Tragoulias S. S., Christopoulos Th. K., Persephonis P., Giannetas V., Ioannou P. Ultrafast fluorescent dynamics of Sybr Green I/DNA complexes // Chem. Phys. Lett.-2010.-485, N 1-3.-P. 187-190.

12. Kryvorotenko D. V., Kostenko O. M., Negrutska V. V., Didan Yu. V., Kolotiuk I. S., Dubey I. Ya. New benziimidazole and quinoline derivatives as topoisomerase I inhibitors: synthesis and biological activity // Annual session of the program «Fundamental problems of the development of new substances and materials for chemical industry»: Abstracts book (Kyiv, December 20, 2012).-Kyiv, 2012.-P. 66-67.

13. Benson S., Singh P., Glazer A. Heterodimeric DNA-binding dyes designed for energy transfer: synthesis and spectroscopic properties // Nucleic Acids Res.-1993.-21, N 24.-P. 5727-5735.

Received 04.04.13 